\title{
PORAZDELITEV TELESNEGA MAŠČEVJA ŠTUDENTK V POVEZAVI S TELESNO AKTIVNOSTJO IN TVEGANJEM ZA OBOLEVNOST KOT POSLEDICO TREBUŠNE DEBELOSTI BODY FAT DISTRIBUTION OF FEMALE STUDENTS RELATED TO PHYSICAL ACTIVITY AND TO RISK OF MORBIDITY DUE TO ABDOMINAL OBESITY Dorjana Zerbo Sporin'
}

Prispelo: 20. 9. 2012 - Sprejeto: 7. 1. 2013

\section{Izvleček}

Izhodišča: Pomanjkanje telesne aktivnosti in neustrezna prehrana lahko pripeljeta do prekomerne mase telesa in povečanega obsega pasu, ki je dejavnik tveganja za pojav bolezni, odvisnih od centralne porazdelitve telesnega maščevja. Namen raziskave je bil ugotoviti, ali je telesna aktivnost študentk povezana s količino in porazdelitvijo maščevja ter oceniti njihovo ogroženost zaradi prekomerne trebušne zamaščenosti.

Metode: Raziskava je bila izvedena na Oddelku za biologijo Biotehniške fakultete v Ljubljani. Spremljano je bilo število tedenskih ur telesne aktivnosti, ki je pomenila kakršnokoli telesno gibanje, ki ga ustvarjajo skeletne mišice in ima kot posledico porabo energije. Študentke Fakultete za šport so bile združene v skupino »športnice « in telesno aktivne večinoma 15 ur tedensko več kot študentke »rekreativke «. Med skupinama so bile primerjane antropometrične vrednosti in ocena porazdelitve telesnega maščevja. $Z$ indeksom pas - boki je bilo ovrednoteno tveganje za pojav bolezni, povezanih s prekomerno količino maščevja $v$ predelu trebuha. Višja stopnja telesne aktivnosti športnic ni bila povezana z vrednostmi telesnih mer in s porazdelitvijo maščevja.

Rezultati: Glavnina študentk izkazuje sorazmerno več maščevja v predelu bokov kot na trebuhu. $5 \%$ študentk sodi v skupino z visokim do zelo visokim tveganjem za pojav bolezni, povezanih s centralnim tipom porazdelitve maščevja. Težje študentke imajo tudi statistično pomembno večji obseg pasu. Z vidika ocenjene količine in porazdelitve telesnega maščevja, se stopnja telesne aktivnosti študentk rekreativk ne razlikuje od tiste, ki jo izvajajo študentke Fakultete za šport.

Zaključki: Večina študentk ima periferno porazdelitev maščevja in nizko do zmerno tveganje za pojav srčno-žilnih bolezni. Potrebno je ustrezno obravnavati posameznice s centralnim tipom porazdelitve maščevja.

Ključne besede: študenti, telesna aktivnost, porazdelitev telesnega maščevja, maščevje na trebuhu, indeks pas - boki, dejavnik tveganja

Original scientific article UDC 612.76:796.012

\begin{abstract}
Background: Lack of physical activity and inadequate nutrition can lead to excessive body weight and increased waist circumference, which is a risk factor for diseases linked to central body fat distribution. The purpose of the study was to determine the relation between the amount of body fat and its distribution to physical activity for female students. Methods: It was also intended to assess their risk of morbidity due to excessive abdominal fatness. The study was conducted at the Department of Biology, Biotechnical Faculty in Ljubljana. Time of weekly physical activity was observed as any bodily movement generated by skeletal muscle and as a result energy consumption. Students of the Faculty of Sports were grouped as "athletes" and physically active most of 15 hours per week more than students
\end{abstract}


from the group "non-athletes". Between them, anthropometric values and body fat distribution were compared. The waist-hip ratio was used for estimation of the risk of ill health associated with abdominal obesity.

Results: Higher level of physical activity for athletes was not associated with typical body dimensions and fat distribution. The majority of female students demonstrated relatively more fat on the hips than on the abdomen. $5 \%$ of them demonstrated high to very high risk for diseases linked to central body fat distribution pattern. Female students with higher body weight have also significantly higher waist circumference. In terms of estimated body fat distribution, the level of physical activity for non-athletes does not differ from that which is carried out by the students of the Faculty of Sports.

Conclusions: Most female students have a peripheral fat distribution and a low to moderate risk for cardiovascular diseases. It is necessary to adequately address individuals with a central fat distribution pattern.

Key words: students, physical activity, body fat distribution, abdominal fat, waist-hip ratio, risk factor

\section{UVOD}

Vzdrževanje priporočene telesne mase ali hujšanje z namenom izgube odvečnih kilogramov nista enostavna procesa. Poleg količinsko in vsebinsko ustrezne prehrane je pomembna tudi redna telesna aktivnost (1-6). Telesna aktivnost pomeni kakršnokoli telesno gibanje, ki ga ustvarjajo skeletne mišice in posledica katerega je poraba energije. Telesna vadba določene zvrsti pa je podkategorija telesne aktivnosti, ki je načrtovana, strukturirana in ponovljiva (7).

Prekomerna masa telesa, še posebej $v$ povezavi $s$ povečano količino maščevja $v$ predelu trebuha, predstavlja dejavnik tveganja za pojav številnih kroničnih nenalezljivih bolezni. To so: bolezni srca in ožilja, povišan krvni tlak, motnje in bolezni presnove, kostno-mišične bolezni in nekatere vrste raka, kot so: rak debelega črevesa in danke ter rak dojke in maternice $(1,14)$. Vzdrževanje priporočene telesne mase in primernega obsega pasu pomembno prispeva k zmanjšanju tveganja za obolevnost. Pri tem je redna telesna aktivnost eden najpomembnejših zaščitnih dejavnikov, ker ugodno vpliva na zdravje tudi neodvisno od prehrane. Krepi srce in ožilje, znižuje raven maščob in sladkorja v krvi, povečuje občutljivost tkiv na inzulin, zmanjšuje tveganje za pojav nekaterih vrst raka, povečuje učinkovitost kostno-mišičnega sistema in tudi izboljša kakovost spanca, olajša premagovanje stresnih situacij in krepi imunski sistem $(4,5,8)$. Nasprotno je pomanjkanje gibanja povezano $z$ debelostjo in $s$ povečanim tveganjem za pojav kroničnih nenalezljivih bolezni ter zgodnejše umiranje odraslih. Pri telesno neaktivnih ljudeh se bolezni srca in ožilja pojavijo $v$ dvakrat večjem obsegu kot pri aktivnih (9). Učinki telesne aktivnosti se lahko kažejo tudi v spremembah sestave telesa. Navadno se zmanjša masa maščevja in poveča masa nemastne telesne komponente, kar se lahko zgodi tudi brez spremembe mase telesa (4, $10,14)$. Sestava telesa se seveda spreminja glede na intenzivnost in zvrst vadbe. Pri določenih športih, ki zahtevajo veliko mišično moč, se masa telesa zaradi večje mišične mase lahko celo poveča (11).

Primerjano $z$ rezultati meritev $z$ neposrednimi metodami za vrednotenje telesnega maščevja, je razmerje med obsegom pasu in bokov (IBP) primerno za oceno porazdelitve maščevja. IPB ni povezan samo s količino podkožnega maščevja, ampak tudi z maščevjem, ki se nahaja okrog organov v trebušni votlini. Višje vrednosti IPB predstavljajo sorazmerno večji delež maščevja na trebuhu kot na bokih. Trebušna debelost je bolj povezana s tveganjem za srčno-žilno obolevnost kot splošna debelost, zato je po ocenah nekaterih avtorjev IPB boljši kazalnik stopnje tveganja kot indeks telesne mase - ITM (12-14, 23). Za mlade odrasle ženske je značilna periferna ali ginoidna porazdelitev maščevja $s$ sorazmerno nizkim deležem maščevja na trebuhu. $\checkmark$ rodnem obdobju se namreč maščevje pretežno nalaga na bokih kot spolno specifično maščevje, ki je pomembno za uspešno oploditev in nemoten potek nosečnosti $(21,22,36)$.

Skrb vzbujajoča je predvsem debelost, ki se pojavi že med mladimi, ker poveča verjetnost debelosti in z njo povezanih bolezni tudi $v$ odrasli dobi $(15,16)$. Mladi, ki niso telesno aktivni, kažejo značilnosti telesne neaktivnosti tudi tudi v odrasli dobi (17). Raziskava o gibanju slovenske mladine je odkrila, da je med poletnimi počitnicami največji odstotek telesno neaktivnih med študenti (16\%) glede na $7 \%$ osnovnošolcev in $14 \%$ srednješolcev (18). Tudi anketiranje študentov v okviru sistematskih pregledov je pokazalo, da se znižuje delež redno športno aktivnih. Povečuje pa se delež študentov, ki se nepravilno prehranjujejo, saj jih ena tretjina večkrat tedensko uživa ocvrto hrano in manj kot polovica jih dnevno uživa sadje in zelenjavo (19).

Zaradi pomembnosti redne telesne aktivnosti v mladosti za zdravo odraslo obdobje in glede na izsledke raziskav, da se zmanjšuje število redno telesno aktivnih študentov, se nam je zdelo smiselno študijo izvesti ravno med študenti. 
Namen raziskave je bil ugotoviti, ali je telesna aktivnost študentk Univerze $v$ Ljubljani povezana z izbranimi telesnimi merami, ki ocenjujejo količino in porazdelitev maščevja. Prav tako je bil namen ovrednotiti porazdelitev telesnega maščevja kot dejavnik tveganja za pojav številnih kroničnih nenalezljivih bolezni, povezanih z debelostjo.

Predpostavljeno je bilo, da imajo študentke, ki so telesno aktivne več ur tedensko, nižjo maso telesa in manj maščevja na trebuhu ter da je povprečni IPB celotnega vzorca značilen za ginoidno ali periferno porazdelitev maščevja. Predvideno je bilo tudi, da študentke obravnavanega vzorca večinoma pripadajo skupinam z nizkim do zmernim tveganjem za pojav bolezni, povezanih s čezmerno količino maščevja, ter da so posameznice s centralnim tipom porazdelitve maščevja težje.

Uporabna vrednost raziskave je ocena porazdelitve telesnega maščevja študentk $v$ povezavi s stopnjo tveganja za pojav bolezni, povezanih s trebušno debelostjo, predvsem bolezni srca in ožilja. Ovrednoten je bil delež že izpostavljenih študentk, pri katerih je treba ukrepati v smeri zmanjšanja tveganja za obolevnost.

\section{METODE}

\subsection{Preiskovanke}

Antropometrično je bilo pregledanih 169 študentk Univerze v Ljubljani, ki so med merjenjem obiskovale različne letnike študija. $V$ raziskavo vključene študentke prihajajo iz vseh slovenskih regij, največ pa jih je iz osrednje Slovenije. V letih izvajanja meritev (1999/2000) so bile v povprečju stare 22 let (Tabela 3 ), kar jih uvršča v zgodnje odraslo obdobje. Študija je bila del doktorske disertacije in izvedena na Oddelku za biologijo Biotehniške fakultete v Ljubljani. Raziskava je bila opravljena skladno z načeli Helsinško-Tokijske deklaracije. Vse merjenke so se za sodelovanje prostovoljno odločile in podpisale pristopno izjavo.

\subsection{Metode za ugotavljanje stopnje telesne aktivnosti preiskovank}

Študentke obravnavanega vzorca so bile anketirane glede števila ur in vrste telesne aktivnosti, ki jo tedensko opravijo. Tiste, ki se niso opredelile za nobeno vrsto namenske telesne aktivnosti, so bile uvrščene $v$ kategorijo nedefinirano. Njihova telesna aktivnost je bila namreč splošna, kot je hoja ali kolesarjenje od doma do fakultete in nazaj, sprehodi itn. (Tabela 1, Slika 1). Raziskave kažejo, da je v Sloveniji telesno aktivnih $76 \%$ mladih odraslih ljudi, in sicer $42 \%$ od enega do dveh dni tedensko, $22 \%$ od tri do štiri dni tedensko in $12 \%$ od pet do sedem dni na teden (20). Tudi $v$ obravnavanem vzorcu je večina študentk $v$ prostem času telesno aktivna več ur v tednu (Tabela 1). Tako enoten vzorec je bilo težko razdeliti v skupine, ki se med seboj razlikujejo $v$ stopnji telesne aktivnosti. Zato je bila znotraj vzorca izbrana skupina študentk, ki odstopa od preostalih, in sicer v urah telesne aktivnosti, ki jih opravijo med študijskim procesom. To so bile študentke Fakultete za šport, za katere je bilo na osnovi anketiranja ugotovljeno, da so že med pedagoškim procesom na fakulteti telesno aktivne v povprečju 11 ur tedensko. Preiskovanke so bile tako razdeljene $\mathrm{v}$ dve skupini, ki sta bili zaradi lažjega sledenja poimenovani: skupina športnic s študentkami Fakultete za šport in skupina rekreativk s študentkami preostalih fakultet (Tabela 2). Vseh rekreativk je bilo 110, športnic pa 59. Športnice so bile telesno aktivne najmanj 11 ur na teden več kot rekreativke. Ker pa je bil največji delež rekreativk (81\%) telesno aktivnih 1-4 ure tedensko, največji delež športnic (64\%) pa 16-18 ur tedensko, se preiskovanke obeh skupin po večini ločujejo v petnajstih urah tedenske telesne aktivnosti (Tabela 1). Večina rekreativk se ni opredelila za nobeno vrsto vadbe, največ športnic pa se je $v$ prostem času ukvarjalo $z$ aerobiko, predvsem kot vaditeljice (Slika 1). 
Tabela 1. Število ur telesne aktivnosti tedensko za športnice in rekreativke.

Table 1. Hours of physical activity per week for athletes and nonathletes.

\begin{tabular}{|l|l|l|l|l|}
\hline \multicolumn{2}{|l|}{ Športnice/Athletes (N=59) } & $5-7$ & $8-10$ & $>10$ \\
\hline $\begin{array}{l}\text { Število ur telesne aktivnosti tedensko v prostem } \\
\text { času/Hours of physical activity per week during } \\
\text { free time }\end{array}$ & $1-4$ & 11 & 11 & 11 \\
\hline $\begin{array}{l}\text { Število ur telesne aktivnosti tedensko med } \\
\text { poukom/Hours of physical activity per week during } \\
\text { school process }\end{array}$ & 11 & $16-18$ & $19-21$ & $>21$ \\
\hline $\begin{array}{l}\text { Število vseh ur telesne aktivnosti tedensko/All } \\
\text { hours of physical activity per week }\end{array}$ & $12-15$ & 16 & $6(10 \%)$ & $3(6 \%)$ \\
\hline Število preiskovank/Number of participants & $12(20 \%)$ & $38(64 \%)$ & & $>10$ \\
\hline Rekreativke/Nonathletes (N=110) & $1-4$ & $5-7$ & $8-10$ & $1(0,8 \%)$ \\
\hline $\begin{array}{l}\text { Število ur telesne aktivnosti tedensko/Hours of } \\
\text { physical activity per week }\end{array}$ & $1-4$ & $17(15,5 \%)$ & $3(2,7 \%)$ & \\
\hline Število preiskovank/Number of participants & $89(81 \%)$ & \multicolumn{2}{|l|}{} \\
\hline
\end{tabular}

$\mathrm{N}=$ število preiskovank/number of participants

Tabela 2. Sestava vzorca glede vpisa na posamezne fakultete Univerze v Ljubljani.

Table 2. Sample structure according to the faculties of the University of Ljubljana.

\begin{tabular}{|l|l|}
\hline Fakulteta/Faculty & Število preiskovank/Numerus of participants \\
\hline Biotehniška fakulteta/Biotechnical faculty & 55 \\
\hline Pedagoška fakulteta/Faculty of education & 42 \\
\hline Fakulteta za farmacijo/Faculty of pharmacy & 4 \\
\hline Ekonomska fakulteta/Faculty of economics & 3 \\
\hline Medicinska fakulteta/Faculty of medicine & 2 \\
\hline $\begin{array}{l}\text { Naravoslovnotehniška fakulteta/Faculty of Natural science } \\
\text { and Engineering }\end{array}$ & 2 \\
\hline Pravna fakulteta/Faculty of law & 1 \\
\hline Fakulteta za družbene vede/Faculty of social science & 1 \\
\hline Fakulteta za šport/Faculty of sport & 59 \\
\hline Skupaj/Total & 169 \\
\hline
\end{tabular}




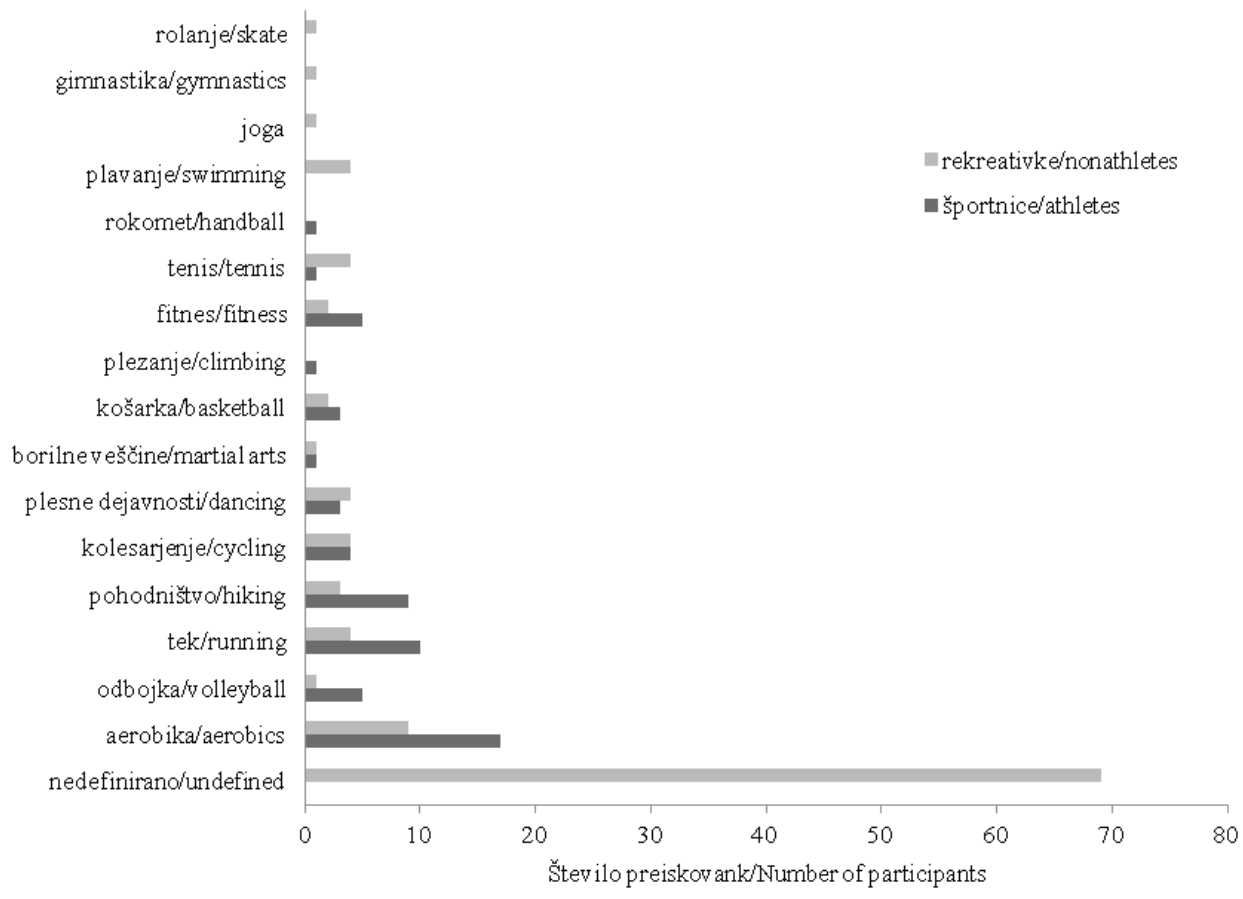

Slika 1. Vrste telesne aktivnosti preiskovank.

Figure 1. Physical activities types for participants.

\subsection{Antropometrične meritve}

Antropometrične meritve so bile izvedene po priporočilih Mednarodnega biološkega programa - IBP (24).

Masa telesa (TM) je bila izmerjena $s$ tehtnico Tanita TBF-305 in izražena v kilogramih. Merjenka, ki je bila oblečena $v$ lahka telovadna oblačila, je bosa stopila na tehtnico. Pri tem je imela maso telesa enakomerno razporejeno na obe nogi.

Obseg pasu (OP) je bil izmerjen tako, da je preiskovanka stala, spuščeni roki je imela nekoliko odmaknjeni od telesa, stopali sta bili skupaj. Merilni trak je bil ovit vodoravno okrog trebuha merjenke. Orientacijski mesti za meritev sta bili: ob strani, polovica razdalje med najnižjo točko prsnega koša in najvišjo točko grebena črevnice, spredaj pa polovica razdalje med hrustančnim podaljškom prsnice in popkom. Roki je nato primaknila $\mathrm{k}$ telesu, vrednost obsega pasu je bila odčitana ob koncu normalnega izdiha (25).

Obseg bokov (OB) je bil izmerjen tako, da je preiskovanka stala, stopali je imela skupaj. Ob telesu spuščeni roki je pomaknila nekoliko nazaj in tako omogočila dostop do mesta meritve. Merilni trak je bil ovit vodoravno okrog bokov merjenke, $v$ višini največje izbočenosti velike zadnjične mišice (26). Obsega sta izražena v centimetrih.

\subsection{Indeks pas - boki (IPB) - vrednotenje razlik med športnicami in rekreativkami}

Porazdelitev vrednosti indeksa pas - boki $v$ obravnavanem vzorcu smo razdelili $v$ tri skupine, omejene $z$ vrednostmi 0,69 in 0,73 , ki sta povprečni IPB vzorca $\pm 0,5$ standardnega odklona (Tabela 3 ).

Skupina IPB 1: vanjo se uvrščajo merjenke z vrednostmi indeksa pas - boki, ki so manjše od 0,69. Dekleta te skupine imajo znotraj porazdelitve vzorca IPB sorazmerno več maščevja na bokih kot na trebuhu. Skupina IPB 2: $v$ to skupino sodijo merjenke $z$ vrednostmi indeksa pas - boki, ki so med 0,69 in 0,73 . Za njih velja, da imajo znotraj porazdelitve obravnavanega vzorca IPB sorazmerno enakomerno razporejeno maščevje med pasom in boki.

Skupina IPB 3: v to skupino so vključene merjenke $z$ vrednostmi indeksa pas - boki, ki so večje od 0,73. Vanjo sodijo študentke, ki imajo znotraj porazdelitve obravnavanega vzorca IPB sorazmerno več maščevja na trebuhu kot na bokih.

\subsection{Indeks pas - boki (IPB) in stopnja tveganja za pojav bolezni, povezanih s centralno porazdelitvijo telesnega maščevja}

Indeks pas - boki je bil izračunan kot količnik med obsegom pasu in bokov in ocenjuje porazdelitev 
telesnega maščevja. Periferna ali ginoidna porazdelitev je značilna za mlajše ženske. Opredeljuje jo sorazmerno večja količina maščevja na bokih $v$ primerjavi $s$ trebuhom in zato nižje vrednosti IPB. Večji indeksi so značilni za osebe, ki imajo v primerjavi z boki zamaščen trebuh. Tovrstna porazdelitev telesnega maščevja je centralna ali androidna in pogostejša med moškimi ter ženskami v obdobju menopavze $(13,14,27)$.

Ker večji IPB pomeni več centralno porazdeljenega maščevja, je tudi pokazatelj stopnje tveganja za obolevnost posameznika. Trebušna debelost je namreč večji dejavnik tveganja od splošne debelosti (28). $\mathrm{Na}$ osnovi vrednosti IPB ter ločeno po spolu in starosti so $\checkmark$ literaturi opredeljeni razredi od nizkega do visokega tveganja za pojav bolezni, ki so posledica centralne porazdelitve maščevja. Študentke, katerih vrednosti IPB so bile manjše od 0,71 , tako sodijo $v$ skupino $z$ nizkim tveganjem. V skupini z vrednostmi IPB med 0,71 in 0,77 so študentke $z$ zmernim, $v$ tisti $z$ indeksi med 0,78 in 0,82 pa študentke $z$ višjim tveganjem. Najvišje tveganje za obolevnost, ki je posledica trebušne debelosti, imajo študentke v skupini z IPB, ki so večji od 0,82 $(13,14)$. Mejniki med razredi $z$ različno stopnjo tveganja se glede na avtorje nekoliko razlikujejo. Po neki drugi opredelitvi kazalnikov, ki je manj restriktivna, so odrasle ženske z abdominalno debelostjo tiste, ki imajo IPB nad 0,80 (29).

\subsection{Statistična obdelava podatkov}

Podatki so bili statistično obdelani s paketom SPSS. Povezanost posameznih spremenljivk je bila ovrednotena s Pearsonovim koeficientom korelacije. Prag statistične pomembnosti je bil 5-odstoten.

Statistična pomembnost razlik v izmerjenih parametrih med športnicami in rekreativkami je bila določena $s$ testom hi-kvadrat.

Razlike v antropometričnih parametrih med športnicami in rekreativkami so bile testirane $\mathrm{z}$ metodo analize variance (ANOVA) $(30,31)$.

\section{REZULTATI}

\subsection{Osnovni parametri}

Preiskovanke obravnavanega vzorca so bile med merjenjem v povprečju stare 22 let. Povprečne vrednosti za izmerjene antropometrične mere so znašale 60,4 kg za maso telesa, $69,3 \mathrm{~cm}$ za obseg pasu in $97,3 \mathrm{~cm}$ za obseg bokov. Povprečni indeks vzorca pas - boki je bil 0,7 , torej imajo študentke $v$ povprečju sorazmerno več maščevja v predelu bokov glede na trebuh. Športnice se $v$ telesni masi, obsegu pasu in bokov ter IPB značilno ne razlikujejo od rekreativk (Tabela 3).

Tabela 3. Izmerjeni in izračunani antropometrični parametri za športnice in rekreativke.

Table 3. Measured and estimated anthropometrical parameters for athletes and nonathletes.

\begin{tabular}{|c|c|c|c|c|}
\hline Parameter & $\begin{array}{l}\text { Vzorec/ } \\
\text { Sample }\end{array}$ & $\begin{array}{l}\text { Športnice/ } \\
\text { Athletes }\end{array}$ & \begin{tabular}{|l} 
Rekreativke/ \\
Nonathletes
\end{tabular} & $p$ \\
\hline & \multicolumn{3}{|l|}{$\mathrm{M} \pm \mathrm{SD}$} & \\
\hline Starost/Age (leta) & $22,0 \pm 2,5$ & / & / & / \\
\hline Telesna masa/Body weight (kg) & $60,4 \pm 8,4$ & $59,9 \pm 5,5$ & $60,6 \pm 9,7$ & 0,64 \\
\hline Obseg pasu/Waist circumference $(\mathrm{cm})$ & $69,3 \pm 5,7$ & $69,0 \pm 3,6$ & $69,5 \pm 6,6$ & 0,62 \\
\hline Obseg bokov/Hip circumference (cm) & $97,3 \pm 6,5$ & $96,2 \pm 4,7$ & $97,9 \pm 7,3$ & 0,10 \\
\hline Indeks pas - boki/Waist - hip ratio & $0,71 \pm 0,03$ & $0,72 \pm 0,03$ & $0,71 \pm 0,04$ & 0,12 \\
\hline
\end{tabular}

* $\quad p<0,05$

$\mathrm{M} \pm \mathrm{SD}=$ povprečje \pm standardni odklon/mean \pm standard deviation

$p=$ statistična pomembnost razlik med skupinama/statistical significance for differences between groups

Študentke $z$ večjim obsegom pasu in/ali bokov so tudi težje. Težje so tudi merjenke z višjimi vrednostmi indeksa pas - boki, torej tiste s sorazmerno več maščevja na trebuhu $v$ primerjavi $z$ boki. Večji obseg pasu je povezan $z$ večjim obsegom bokov (Tabela 4). 
Tabela 4. Korelacijski koeficienti med antropometričnimi merami.

Table 4. Correlation coefficients for anthropometric parameters.

\begin{tabular}{|l|l|l|}
\hline Parameter & $\begin{array}{l}\text { Telesna teža/Body } \\
\text { weight }(\mathrm{kg})\end{array}$ & $\begin{array}{l}\text { Obseg pasu/Waist } \\
\text { circumference }(\mathrm{cm})\end{array}$ \\
\hline $\begin{array}{l}\text { Obseg pasu/Waist circumference } \\
(\mathrm{cm})\end{array}$ & $0,85^{*}$ & 1,00 \\
\hline $\begin{array}{l}\text { Obseg bokov/Hip circumference } \\
(\mathrm{cm})\end{array}$ & $0,91^{*}$ & $0,78^{*}$ \\
\hline $\begin{array}{l}\text { Indeks pas - boki/Waist - hip } \\
\text { ratio }\end{array}$ & $0,16^{*}$ & $/$ \\
\hline
\end{tabular}

${ }^{*} r \geq 0.16 \quad p<0.05$

\subsection{Indeks pas - boki (IPB) - vrednotenje razlik med športnicami in rekreativkami}

Skupina IPB 1 zajema $30,8 \%$ celotne porazdelitve vrednosti IPB; v njej je 52 študentk, 22\% izmed vseh športnic in 35,5\% izmed vseh rekreativk.

Skupina IPB 2 zajema 40,8\% celotne porazdelitve vrednosti IPB; v njej je 69 študentk, in sicer 40,7\% izmed vseh športnic in 40,9\% izmed vseh rekreativk.
Skupina IPB 3 z 48 študentkami zajema $28,4 \%$ celotne porazdelitve vrednosti IPB. Vanjo sodi $37,3 \%$ izmed vseh športnic in $23,6 \%$ izmed vseh rekreativk (Tabela 5, Slika 2).

Dejanski hi-kvadrat(4,86) ne presega teoretičnega $(5,99)$, torej se športnice in rekreativke ne razlikujejo $v$ porazdelitvi v skupine IPB 1-3 (Tabela 5).

Tabela 5. Kontingenčna tabela za skupine znotraj porazdelitve vrednosti indeksa pas - boki.

Table 5. Contingency table for groups within waist-hip ratio distribution.

\begin{tabular}{|l|l|l|l|l|l|}
\hline $\begin{array}{l}\text { IPB- } \\
\text { skupine } \\
\text { IPB- } \\
\text { groups }\end{array}$ & \multicolumn{2}{|l|}{$\begin{array}{l}\text { Število športnic/ } \\
\text { Number of athletes }\end{array}$} & \multicolumn{2}{|l|}{$\begin{array}{l}\text { Število rekreativk/ } \\
\text { Number of nonathletes }\end{array}$} & $\begin{array}{l}\text { Dejanski } \lambda^{2} / \\
\text { Observed } \lambda^{2}\end{array}$ \\
\hline & $\begin{array}{l}\text { Dejansko } \\
\text { število/ } \\
\text { Observed } \\
\text { number }\end{array}$ & $\begin{array}{l}\text { Pričakovano } \\
\text { število/ } \\
\text { Expected } \\
\text { number }\end{array}$ & $\begin{array}{l}\text { Dejansko } \\
\text { število/ } \\
\text { Observed } \\
\text { number }\end{array}$ & $\begin{array}{l}\text { Pričakovano } \\
\text { število/ } \\
\text { Expected } \\
\text { number }\end{array}$ & 4,86 \\
\hline IPB 1 & 13 & 18 & 39 & $34(30,8 \%)$ & Predvideni $\lambda^{2} /$ \\
\hline IPB 2 & 24 & 24 & 45 & $45(40,8 \%)$ & Predicted $\lambda^{2}$ \\
\hline IPB 3 & 22 & 17 & 26 & $31(28,4 \%)$ & 5,99 \\
\hline $\begin{array}{l}\text { Skupaj/ } \\
\text { Total }\end{array}$ & 59 & 59 & 110 & 110 & \\
\hline
\end{tabular}

IPB 1= relativno več maščevja na bokih kot na trebuhu/relatively more fat on the hips than on the abdomen IPB 2= sorazmerno maščevje na bokih in trebuhu/uniform fat distribution on the hips and on the abdomen IPB $3=$ relativno več maščevja na trebuhu kot na bokih/relatively more abdominal fat than fat on the hips 


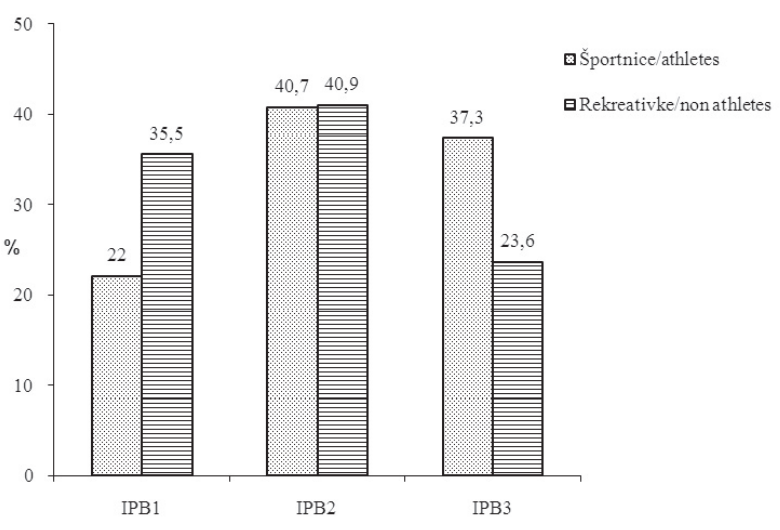

Skupine znotraj porazdelitve vrednosti indeksa pas-boki (IPB)/Groups within waist-hip ratio distribution (IPB)

IPB 1= sorazmerno več maščevja na bokih kot na trebuhu/ relatively more fat on the hips than on the abdomen IPB 2= sorazmerno maščevje na bokih in trebuhu/uniform fat distribution on the hips and on the abdomen

IPB 3= sorazmerno več maščevja na trebuhu kot na bokih/ relatively more abdominal fat than fat on the hips

Slika 2. Odstotek športnic in rekreativk $v$ skupinah znotraj porazdelitve vrednosti indeksa pas - boki.

Figure 2. Percent of athletes and non athletes in groups within waist-hip ratio distribution.

\subsection{Porazdelitev preiskovank $v$ razrede $z$ različnimi stopnjami tveganja za pojav bolezni, povezanih s centralno porazdelitvijo telesnega maščevja}

Glede na vrednost IPB ima večina preiskovank nizko do zmerno tveganje za pojav bolezni, ki so povezane s trebušno debelostjo (Tabela 6). $V$ skupino z nizkim tveganjem se je uvrstilo 73 študentk (43\%) in v skupino z zmernim tveganjem 87 študentk (52\%). 7 študentk (4\%) pripada skupini z visokim tveganjem in 2 študentki
(1\%) skupini z zelo visokim tveganjem za pojav bolezni, povezanih s centralnim tipom debelosti.

\section{RAZPRAVA}

Kot je bilo v uvodu predvideno, je telesna masa študentk tudi dejansko povezana z vrednostmi indeksa pas - boki (IPB). Študentke z višjimi indeksi, za katere je značilno sorazmerno več maščevja okrog pasu v primerjavi $z$ boki, so težje (Tabela 4). Opaženo sovpada z dejstvom, da je centralna porazdelitev maščevja povezana $s$ prekomerno telesno maso in $z$ debelostjo $(1,4,21)$. Ugotovljena je bila značilna pozitivna korelacija telesne mase in obeh obsegov (Tabela 4). Kot je že znano, se z zniževanjem mase telesa zmanjšuje tudi obseg pasu. Obseg pasu je kot ocena trebušne zamaščenosti pogosto uporabljen kazalnik ogroženosti posameznika za pojav srčno-žilnih bolezni. V preventivnih programih se namreč upoštevajo mejne vrednosti obsega pasu, in sicer za ženske več od $80 \mathrm{~cm}$ kot ogroženost in več od $88 \mathrm{~cm}$ kot visoka ogroženost za pojav bolezni srca in ožilja (28). Povprečni obseg pasu obravnavanega vzorca je 69,3 cm (Tabela 3), kar pove, da študentke v povprečju nimajo povečanega tveganja za pojav bolezni srca in ožilja. Ne gre pa povsem izključiti možnosti, da sta večji obseg pasu in bokov nekaterih preiskovank lahko povezana $z$ več mišične in ne nujno maščobne mase. Zato bi seveda morali določiti lokalno sestavo telesa.

Kot je bilo na začetku predvideno, je dejanska povprečna vrednost vzorca IPB (Tabela 3 ) značilna za ginoidno ali periferno porazdelitev maščevja mladih odraslih žensk, ki je pomembna za uspešno oploditev in nemoten potek nosečnosti $(1,4,27,36)$. Podobne vrednosti IPB ugotavljajo tudi drugi avtorji, in sicer v povprečju 0,75 za mlade odrasle ženske, stare od 18 do 24 let (29).

Tabela 6. Porazdelitev preiskovank $v$ skupine $z$ različnim tveganjem za pojav bolezni, povezanih s trebušno debelostjo.

Table 6. Participants distribution in different risk categories for development of abdominal obesity related diseases.

\begin{tabular}{|l|l|l|l|}
\hline $\begin{array}{l}\text { Stopnja tveganja/Risk } \\
\text { categories }\end{array}$ & $\begin{array}{l}\text { Indeks pas -boki/ } \\
\text { Waist-hip ratio }\end{array}$ & $\begin{array}{l}\text { Število preiskovank } \\
\text { /Number of } \\
\text { participants }\end{array}$ & $\begin{array}{l}\text { Odstotek preiskovank (\%) } \\
\text { /Percent of participants (\%) }\end{array}$ \\
\hline Nizko/Low & $<0,71$ & 73 & 43 \\
\hline Zmerno/Moderate & $0,71<\mathrm{IPB}<0,77$ & 87 & 52 \\
\hline Visoko/High & $0,78<\mathrm{IPB}<0,82$ & 7 & 4 \\
\hline Zelo visoko/Very high & $>0,82$ & 2 & 1 \\
\hline
\end{tabular}


Predpostavljeno, da imajo študentke, ki so telesno aktivne več ur tedensko, nižjo telesno maso in manj maščevja okrog pasu, $v$ raziskavi ni bilo potrjeno. Športnice in rekreativke raziskovanega vzorca se namreč ne razlikujejo $v$ nobenem izmerjenem antropometričnem parametru (Tabela 3). Tudi pretekle slovenske raziskave navajajo, da se telesno aktivni in neaktivni študenti niso značilno razlikovali $v$ telesnih obsegih (33). Obravnavani skupini sta se ločevali v številu ur tedenske telesne aktivnosti, in sicer za najmanj enajst, večinoma pa za petnajst ur (Tabela 1). Drugi dejavniki, kot sta na primer količina in vsebina zaužite hrane, ki tudi pomembno vplivata na dimenzije telesa, $v$ raziskavi niso bili spremljani (1-3). Ohranjanje priporočljive telesne mase je najučinkovitejše $s$ kombinacijo primernega vnosa energije s hrano in porabo energije $z$ ustrezno telesno aktivnostjo (34). Za nadzor količine telesnega maščevja je gibanje torej pomembno, vendar samo ni zadostno. Podobnost antropometričnih mer med skupinama športnice in rekreativke je mogoče pojasniti tudi z drugimi razlagami, tj. da so se športnice prehranjevale manj ustrezno od rekreativk ali da je bila stopnja telesne aktivnosti rekreativk zadostna za vzdrževanje primerne telesne mase, obsega pasu in vrednosti IPB. Ne nazadnje Svetovna zdravstvena organizacija odraslim priporoča najmanj 30 minut zmerne do intenzivne aerobne telesne aktivnosti vsaj petkrat tedensko in dvakrat tedensko vaje za moč $z$ namenom izboljšanja srčno-žilne in kostno-mišične kondicije ter vzdrževanja želene telesne mase (35). Vsekakor bi bilo za vrednotenje povezanosti stopnje telesne aktivnosti in antropometričnih mer v prihodnje smiselno raziskavo nadgraditi s spremljanjem prehranjevalnih navad študentk. Redna telesna aktivnost pa je vsekakor eden najpomembnejših zaščitnih dejavnikov pri preprečevanju pojava bolezni, povezanih z debelostjo in $s$ centralnim tipom porazdelitve maščevja ter zato eden izmed ključnih stebrov preventive $v$ zdravstvu $(1,4,5,8)$.

Med športnicami in rekreativkami ni bilo opaziti pomembne razlike $v$ porazdelitvi vrednosti IPB $v$ podskupine (Tabela 5), torej imajo podoben odstotek predstavnic z nižjimi, vmesnimi in z višjimi vrednostmi IPB. Povezave presežka tedenskih ur telesne aktivnosti športnic s porazdelitvijo telesnega maščevja v obravnavanem vzorcu ni. Iz literature pa je znano, da se pri vrhunskih športnicah porazdelitev telesnega maščevja spremeni, kar je najverjetneje povezano $z$ zelo intenzivnimi in daljšimi treningi $(32,38)$.

Mogoče je tudi, da imajo dekleta obeh skupin primerljivo porazdelitev IPB zaradi starostne enotnosti vzorca. Za mlade odrasle ženske je namreč značilna hormonsko odvisna periferna ali ginoidna porazdelitev maščevja $(21,22)$. Navedeno bi seveda bilo mogoče potrditi le, če bi v raziskavi spremljali tudi hormonsko sliko merjenk. Kot je bilo predvideno, ima večina preiskovank $(95 \%)$ po klasifikaciji za IPB (14) nizko do zmerno tveganje za pojav bolezni, ki so povezane s trebušno debelostjo, s poudarkom na srčno-žilnih boleznih (Tabela 6). Opaženo je bilo pričakovati, saj so v vzorcu mlade odrasle ženske s periferno porazdelitvijo maščevja, ki je v nasprotju s centralno enačena $z$ nižjim tveganjem za obolevnost. Pozneje, s približevanjem menopavzi, se ženskam porazdelitev telesnega maščevja postopoma spreminja. Povečuje se delež tistih s centralno porazdelitvijo, ki pa predstavlja povečano tveganje za pojav številnih kroničnih nenalezljivih bolezni (12, 14, 21). Vsekakor se je treba nemudoma posvetiti sedmim študentkam, ovrednotenim z visokim ter dvema študentkama z zelo visokim tveganjem za pojav bolezni, povezanih s centralno debelostjo (Tabela 6). Poleg priporočil o pomenu uživanja pestre prehrane $v$ omejenih količinah in ustrezni telesni aktivnosti, jih je smiselno napotiti do strokovnjakov, usposobljenih za vodenje redukcijske diete $z$ namenom izgube odvečnih kilogramov in zmanjšanja obsega pasu. Tudi vse preostale študentke, predvsem tiste iz skupine $z$ zmernim tveganjem (Tabela 6), je treba ozaveščati o pomembnosti primernega življenjskega sloga v mladosti za zdravje v odraslem obdobju.

\section{ZAKLJUČEK}

Študentje v svojih delovnih okoljih pretežno sedijo. Predhodne raziskave so pokazale, da se povečuje delež študentov, ki se ne gibljejo redno, in tistih, ki se nepravilno prehranjujejo $(18,19)$. Oboje lahko povečuje telesno maso in obseg pasu, ki je neodvisno od splošne zamaščenosti dejavnik tveganja za pojav bolezni, povezanih s trebušno debelostjo, predvsem srčno-žilnih $(1,9,14,28)$. V obravnavanem vzorcu so bile študentke športnice telesno aktivne najmanj 11 ur tedensko več od rekreativk. Ugotovljeno je bilo, da višja stopnja telesne aktivnosti športnic ni povezana z značilnimi vrednostmi telesnih mer in s porazdelitvijo maščevja. $S$ tega vidika se stopnja telesne aktivnosti študentk rekreativk pomembno ne razlikuje od tiste, ki jo izvajajo študentke Fakultete za šport, kar je spodbudno. Glede na povprečni indeks vzorca pas - boki imajo študentke več maščevja v predelu bokov kot na trebuhu. Tovrstna ginoidna ali periferna porazdelitev maščevja je za mlade odrasle značilna in potrebna za uspešno 
oploditev in nemoten potek nosečnosti $(21,22,36)$. Večina študentk vzorca (95\%) ima po klasifikaciji IPB (14) nizko do zmerno tveganje za pojav bolezni, ki so povezane s trebušno debelostjo. Indeks pas - boki je enostaven, vendar uporaben kazalnik stopnje ogroženosti za pojav bolezni srca in ožilja, saj je centralna porazdelitev maščevja za zdravje še posebej nevarna $(14,28,29)$. Na podlagi uporabljene metode lahko prepoznamo izpostavljene posameznike, v dotični raziskavi jih je bilo $5 \%$, in jih ustrezno obravnavamo z namenom izgube odvečnih kilogramov, zmanjšanja obsega pasu in tveganja za obolevnost. Preostale pa ciljano ozaveščamo o pomembnosti primernega življenjskega sloga $v$ mladosti za zdravje $v$ odraslem obdobju.

Za nadaljnje vrednotenje povezave telesne aktivnosti $s$ količino in porazdelitvijo maščevja bi bilo potrebno nadzirati tudi prehranske navade, ki pomembno vplivajo na dimenzije telesa. Za ohranitev priporočene mase telesa in obsega pasu je gibanje namreč pomembno, vendar samo ni zadostno. Najučinkovitejša je kombinacija primernega vnosa energije s hrano in porabe energije z ustrezno telesno aktivnostjo (34). Smiselno bi bilo raziskati tudi povezanost telesne aktivnosti ali celo posamezne vrste športa z regionalno sestavo telesa.

\section{Zahvala}

Kolegicama Mariji Štefančič in Tatjani Tomazo-Ravnik se zahvaljujem za strokovno podporo. Hvala vsem preiskovankam za sodelovanje $\mathrm{v}$ raziskavi.

\section{Literatura}

1. McArdle W, Katch F, Katch V. Physical activity, health and aging. In: McArdle W, Katch F, Katch V, editors. Exercise physiology: energy, nutrition and human performance. 7th ed. Maryland, Baltimore: Wiliams \& Wilkins, 2010: 831-875.

2. Epstein LH, Roemmich JN, Cavanaugh MD, Paluch RA. The motivation to be sedentary predicts weight change when sedentary behaviours are reduced. Int J Behav Nutr Phys Act 2011; 22: 8-13.

3. Wing RR, Hill JO. Successfull weight loss maintenance. Annu Rev Nutr 2001; 21; 323-341.

4. Mišigoj-Duraković M. Debelost. In: Kovač M, Strel J, MišigojDuraković M, editors. Telesna vadba in zdravje. Ljubljana: Zveza društev športnih pedagogov Slovenije, 2003: 154-163.

5. Lee I, Djoussé L, Sesso HD, Wang L, Buring JE. Physical activity and weight gain prevention. JAMA 2010; 303: 1173-1179.

6. Field A, Haines J, Rosner B, Willett WC. Weight-control behaviors and subsequent weight change among adolescents and young adult females. Am J Clin Nutr 2010: 91: 147-153.

7. Caspersen CJ, Powell KE, Christenson GM. Physical activity, exercise, and physical fitness: definitions and distinctions for health-related research. Public Health Rep 1985; 100; 126-131.
8. Lee IM, Paffenbarger RS Jr, Hennekens $\mathrm{CH}$. Physical activity, physical fitness and longevity. Aging 1997; (1-2): 2-11.

9. Warren TY, Barry V, Hooker SP, Sui X, Church TS, Blair SN. Sedentary behaviors increase risk of cardiovascular disease mortality in men. Med Sci Sports Exerc 2010; 42: 879-885.

10. Lohman TG, Ring K, Pfeiffer K, Camhi S, Arredondo E, Pratt C, Pate R, Webber LS. Relationships among fitness, body composition, and physical activity. Med Sci Sports Exerc 2008; 40: 1163-1170.

11. Bouchard C. Physique, performance anh physical activity. In: McArdle W, Katch F, Katch V, editors. Exercise physiology: energy, nutrition and human performance. 7th ed. Maryland, Baltimore: Wiliams \& Wilkins, 2010: 759-779.

12. Malina RM. Regional body composition: age, sex, and ethnic variation. In: Roche AF, Heymsfield SB, Lohman TG, editors. Human body composition. Champaing: Human Kinetics, 1996: 217-255.

13. Heyward VH, Stolarczyk LM. Applied body composition assessment. Champaing: Human Kinetics, 1996.

14. Bray GA, Gray DS. Obesity: part I: pathogenesis. West J Med 1988; 149: 429-441.

15. Koster A, Harris TB, Moore SC, Schatzkin A, Hollenbeck AR Ejik J, Leitzmann MF. Joint associations of adiposity and physical activity with mortality: the National Institutes of Health - AARP diet and health study. Am J Epidemiol 2009; 169: 1344-1351.

16. Truesdale KP, Stevens J, Lewis CE, Schreiner PJ, Loria CM, Cai $J$. Changes in risk factors for cardiovascular disease by baseline weight status in young adults who maintain or gain weight over 15 years: the CARDIA study. Int J Obes; 30: 1397-1407.

17. Telama R. Tracking of physical activity from childhood to adulthood: a review. Obes Facts 2009; 2: 187-195.

18. Jurak G, Strel J, Kovač M. Sports activities and lifestyle of slovenian children and youth during their summer holidays. Metodika 2009; 19: 451-465.

19. Miholič M. Ocena zdravstvenega stanja in sočasne bolezni študentov. In: Kersnik J, editor. Sočasne bolezni in stanja. Ljubljana: Zbirka PIP, Združenje zdravnikov družinske medicine SZD, 2005: 195-200.

20. Djomba JK, Zaletel-Kragelj L, Maučec-Zakotnik J, Fras Z. Tvegana vedenja, povezana z zdravjem in nekatera zdravstvena stanja pri odraslih prebivalcih Slovenije. Ljubljana: Inštitut za varovanje zdravja RS, 2010.

21. Kirchengast S, Gruber D, Sator M, Knogler W, Huber J. The fat distribution index a new possibility to quantify sex specific fat patterning in females. Homo 1997; 48: 285-295.

22. Kirchengast $\mathrm{S}$. Interactions between somatometric parameters and endogenus hormone levels as well as hormonal induced events in females. Anthropologischer Anzeiger 1996; 56: 251265.

23. Van Dijk SB, Takken T, Prinsen EC, Wittink H. Different anthropometric adiposity measures and their association with cardiovascular disease risk factors: a meta-analysis. Neth Heart J 2012; 20: 208-218.

24. Weiner JS, Lourie JA. Human biology: a guide to field methods. Oxford: Burgess and Son Press, 1996.

25. Tran ZV, Weltman A. Generalized equations for predicting body density of women from girth measurements. Med Sci Sports Exerc 1989; 21: 101-104.

26. Lohman TG. Skinfolds and body density and their relation to body fatness: a review. Hum Biol 1981; 5: 181-225.

27. Malina RM. Regional body composition: age, sex, and ethnic variation. In: Roche AF, Heymsfield SB, Lohman TG, editors. Human body composition. Champaign: Human Kinetics, 1996: 217-255. 
28. Kravos A. Debelost in pridružene bolezni. In: Kersnik J, editor. Sočasne bolezni in stanja. Ljubljana: Zbirka PIP, Združenje zdravnikov družinske medicine SZD, 2005: 59-70.

29. Dobbelsteyn CJ, Joffres MR, MacLean DR, Flowerdew G. A comparative evaluation of waist circumference, waist-to-hip ratio and body mass index as indicators of cardiovascular risk factors: the Canadian Heart Health Surveys. Int J Obes Relat Metab Disord 2001; 25: 652-661.

30. Adamič Š. Temelji biostatistike. 2. izd. Ljubljana: Univerza Edvarda Kardelja v Ljubljani, Medicinska Fakulteta, 1989.

31. Madrigal L. Statistics for anthropology. Cambridge: Cambridge University Press, 1998.

32. Malina RM, Mueller WH, Bouchard C, Shoup RF, Lariviere G. Fatness and fat patterning among athlets at the Montreal Olimpic Games, 1976. Med Sci Sports Exerc 1982; 14: 445-452.

33. Štefančič $M$, Tomazo-Ravnik $T$. Vpliv športne aktivnosti na nekatere morfološke karakteristike ljubljanskih študentov in sekularne razvojne tendence pri športnikih. Biol Vestn 1992; 40: 27-34.

34. Blinc A, Bresjanac M. Telesna dejavnost in zdravje. Zdrav vest 2005; 74: 771-777.

35. Engelsman V, Collazos N, Moindot C, Sherer A. Recommended population levels of physical activity for health: age group: 18-64 years old: In: Gaggero CV, Pierre MC, editors. Global recommendation on physical activity for health. Geneva: World Health Organization, 2010; 11-33.

36. Campaigne BN. Body fat distribution in females: metabolic consequences and implications for weight loss. Med Sci Sports Exerc 1990; 22: 291-297.

37. Heyward VH, Stolarczyk LM. Applied body composition assessment. Champaign: Human Kinetics, 1996.

38. Ramirez ME, Heinrich KK. Effects of training on body composition and subcutaneus fat distribution in women gymnasts. Am J Hum Biol 1993; 5: 523-528. 